\title{
The Role of Islamic Development and Kemuhammadiyahan in Increasing Employee Values of Muhammadiyah University of Ponorogo
}

\author{
Riyanto $^{1}$, Sigit Dwi Laksana ${ }^{2}$, Ayok Ariyanto ${ }^{3}$ \\ \{riyanto.ump84@gmail.com ${ }^{1}$ \}
}

Fakultas Agama Islam, Universitas Muhammadiyah Ponorogo, Indonesia ${ }^{1,2,3}$

\begin{abstract}
This study aims to investigate the implementation, methods, and roles as one of the scientific reference materials to improve the quality of formation programs of Al-Islam and Kemuhammadiyahan in instilling the values of religiosity for Muhammadiyah University Ponorogo's Employees. This research included the type of qualitative field research with a background of Al-Islam and Kemuhammadiyahan formation for employees at Muhammadiyah University of Ponorogo. The collection of data is done using interviews, observation, and documentation. Data analysis uses descriptive analysis. The results showed that: 1). Implementation of Formation can be improved to foster selfawareness and the importance of following this formation seriously. 2). The method used in this formation is the method of individual and group counseling. The other methods using exemplary, habituation, advice, lecturing, discussion, storytelling, and memorization. 3). Al-Islam and Kemuhammadiyahan's formation gives a significant role in instilling values of employee religiosity.
\end{abstract}

Keywords: Al-Islam, kemuhammadiyahan, values of religiosity

\section{Introduction}

Islam is the religion of Allah that was revealed to the Apostles, as Allah's guidance and grace for mankind throughout the ages, which guarantees the welfare of material and spiritual life, worldly and ukhrawi [1]. Islam, namely the Islamic religion brought by the Prophet Muhammad as the Prophet of the end of time, is the teachings revealed by Allah that are contained in the Al-Quran and the authentic Sunnah of the Prophet (maqbul) in the form of commands, prohibitions, and instructions [2]. for the good of human life in this world and the hereafter. Islamic teachings are comprehensive and cannot be separated from one another, covering the fields of aqidah, morality, worship, and mu'amalah duniawiyah.

To create a happy and safe society as mentioned above, everyone, especially Muslims, people who believe in Allah and the following day, are obliged to follow in the footsteps of all the holy prophets, worship Allah and try as hard as possible to gather all strength and with sincere and sincere intentions for Allah solely and only expecting the grace of Allah and His blessing alone. So, one way to make this happen on the 8th Dzulhiijah 1330 Hijriyah or 18 November 1912 Miladiyah, to realize these ideals KHA. Dahlan founded an organization as an "Islamic movement" under the name "Muhammadiyah" with the intent and purpose of 
upholding and upholding the Islamic Religion so that the real Islamic community could be realized [3].

Muhammadiyah University of Ponorogo is an educational unit belonging to the Muhammadiyah Association that organizes higher education, in charge of providing education, learning, research, and community service as well as Al-Islam and Kemuhammadiyahan, always trying to improve the quality of human resources, especially to instill religious values for its employees [4].

The reality in the field shows that in general, employees at the Muhammadiyah University of Ponorogo have low enthusiasm in the application of the values of Al-Islam and Muhammadiyah, including (1) Discipline for attendance at workplaces of employees, especially lecturers and structural officials, (2) Low attendance levels employees at the time of holding AlIslam and Muhammadiyah development activities (3) Low level of mastery of reading AlQur'an (4) Low interest of Muhammadiyah Ponorogo University employees who are actively involved in the management of Muhammadiyah / Aisyiyah at various levels of leadership [4].

The solution to the above problems needs to be made efforts to improve the development of Al-Islam and Muhammadiyah for Muhammadiyah University employees of Ponorogo that are planned, systematic and sustainable with programs to instill religious values for employees, including holding written tests and AIK interviews every time there is a recruitment for a new employee candidate. Organizing recitation activities on Sunday Morning Al-Manar, training in translating the Koran with the tamyiz method, training in tajwid and reading the Koran using the Muri-Q method, kultum after each dzuhur prayer every Thursday and Monday, assistance in reading Al -Quran every day according to the schedule of each work unit, an appeal to read the Qur'an before starting work, obligatory prayers in congregation and duha prayers and so on [2].

The role of AIK Development at Muhammadiyah Ponorogo University is the driving spirit and the main mission of implementing the higher education process [5]. The development of AIK is also a spiritual, moral, intellectual strength and also as an identity for the character of the Muhammadiyah University of Ponorogo academic community, namely, as a Muslim who has good morals, is intelligent, progressive, has a leadership spirit, and cares for personal, community, and national problems for all Muhammadiyah University employees. Ponorogo. AIK coaching for employees if it can be carried out sustainably and evaluating the activities that have been carried out then improving the material, methodology, regulatory management resources, and supporting policies will make it easier to achieve the desired goals [6].

Therefore, a comprehensive evaluation is needed to measure the quality of Al-Islam and Muhammadiyah Development at the Muhammadiyah University of Ponorogo [7]. Is its existence able to provide a positive role to employees or is it still a formality that has not yet touched the objectives of coaching. However, in reality, there are not many Muhammadiyah universities that can implement these lofty ideals. Likewise, what happened at Muhammadiyah University of Ponorogo, which intellectually, could produce its graduates to become professional Muslim scholars in their fields, but in realizing the main mission of Muhammadiyah Higher Education, namely the Development of AIK can be a basis for spiritual or religious and moral strength for the entire academic community [2]. has not been going well, so this fact is what encourages the author to know the extent of the role of AIK Development in instilling religious values of Muhammadiyah University of Ponorogo's employees. 


\section{Method}

This research is qualitative research [8] with the research method used is descriptive qualitative. Descriptive qualitative research is in the form of research with a method or case study approach with data collection techniques: a) Observation. Observation is usually defined as "systematic observation and recording of the symptoms that appear on the research object". The symptoms referred to are matters related to the inculcation of employee religious values. From these observations, the researcher will systematically record the symptoms that appear on the surface, which are related to the implementation of employee development programs. b) Indepth Interview (Deep Interview) Interview is a technique carried out by communicating with data sources through dialogue (question and answer) orally, this interview is carried out to the Daily Advisory Board and the Human Resources Division. The things that were then asked were matters relating to how the process of inculcating the religious value of employees. c) Documentation, this method is used as a means of photographing various events and activities relating to the form of activities, forms of religious studies carried out by the institution [9].

Data analysis was performed during data collection in the field and after all, data was collected, using the Miles Huberman analysis technique [8]. Data analysis takes place simultaneously which is carried out simultaneously with the data collection process with a flow of stages: data collection, data reduction (data display), conclusions or verification (concluding, drawing, and verifying).

\section{Results and Discussion}

\subsection{Coaching background}

Muhammadiyah University of Ponorogo as one of the institutions under the Muhammadiyah Association always tries to improve the quality of its Human Resources (HR) to improve the quality and productivity of the institution [10]. This quality improvement is not only by fulfilling welfare needs in the material aspect and physical needs but also by fulfilling spiritual needs. Development of Al-Islam and Kemuhammadiyahan is one of the businesses that have the biggest role in fulfilling needs in this spiritual field. Religion has a dominant role in shaping a person's attitude and behavior. The higher the level of faith and devotion, the better the attitude and behavior.

It is hoped that the religious values that have been implanted in him will give rise to commendable attitudes and behaviors, such as being honest, disciplined, friendly, trustworthy, responsible, and so on. These commendable attitudes and behaviors are very important to improve the quality and work productivity of employees of the Muhammadiyah University of Ponorogo. Based on the results of interviews with Drs. H. Aries Sudarly Yusuf as secretary of the Muhammadiyah University of Ponorogo Daily Development Board (BPH) that to instill the values of religious values for all employees, is expected to seriously participate in the coaching program carried out by Muhammadiyah Ponorogo University [4].

\subsection{Implementation of development}

The implementation of Al-Islam and Muhammadiyah Development (AIK) for employees (lecturers, employees, and structural officials) is carried out by the Islamic Da'wah Research, 
Development and Development Agency (BP3DI) whose coordination is directly controlled by the Chancellor of Muhammadiyah of Ponorogo University. There are several forms of Al-Islam and Kemuhammadiyaha guidance for employees that have been carried out so far, namely: Studies, Learning to Read Al-Qur'an, I'tikaf Ramadan, and Recitation [2].

\subsection{Development program}

The AIK coaching program for employees so far has not had an orderly and neat program in the form of a curriculum, so that materials that have been presented are often presented again during the next AIK coaching period. Among the structural officials, the studies that have been carried out so far still emphasize materials that are spiritual in nature, and such material is generally only suitable for employees. Meanwhile, there is very little material that is thoughtprovoking [11]. Meanwhile, the lecturers need more material that is thoughtful in nature and less material that is spiritual in nature.

\subsection{Methods of inculcating religious values}

The method for instilling religious values for employees of Muhammadiyah University of Ponorogo is specifically for new employees to hold pre-service activities and interviews with Al-Islam and Muhammadiyah commitments every time they renew their contracts, while for old employees' interviews are held for renewal of work commitments and Al-Islam. and Kemuhammadiyahan. The next program will establish Muhammadiyah and Aisyiyah branches at Muhammadiyah Ponorogo of University [4].

\subsection{Role of formation}

To get the desired research results, according to the objectives and interview questions, the researcher took several informants who were considered to be related to the role of Al-Islam and Muhammadiyah development at the Muhammadiyah University of Ponorogo, namely the head of BP3DI, AIK lecturers, non-Al-Islam and Muhammadiyah lecturers [2]. and Muhammadiyah University employees Ponorogo towards instilling religious values. So, the most important role, especially the leadership in fostering the Al-Islam and Muhammadiyah programs, is a matter of courage and assertiveness to make coaching policies.

The supporting factor for the success of the role of fostering Al-Islam and Kemuhammadiyahan to instill the religious values of employees is the existence of a wellprogrammed development planning system and the existence of continuous evaluation of activities. Besides, the existence of role models from the leadership and fellow employees will be able to provide a very broad opportunity to internalize the values of Islamic life which were deliberately built by the University of Muhammadiyah Ponorogo. Second, physical facilities in the form of mosques and libraries that are representative of worship and learning facilities [6]. The third is the Information Technology system that can add to employee information. The fourth is coaching activity coaches who meet the qualifications because they are activists with a background in the teaching or teacher profession, supported by comfortable environmental conditions, without any mental and moral tension of the employees.

The obstacle is the heterogeneity of employees' backgrounds in reading and writing skills of the Qur'an and worship as well as the habits of daily religious life. The solution from the researcher is to build an attitude of employee togetherness in the form of joint activities [1]. The two inhibiting factors in the coaching process are lecturers' busy teaching schedules and the 
busyness of each employee who cannot leave. The solution is to set a coaching schedule according to the leeway of each employee. The obstacles in terms of the implementation time of Al-Islam and Muhammadiyah guidance are the lack of implementation time, and the lack of literature related to Islamic and Muhammadiyah Development so that it often causes difficulties in finding and confirming something related to religious matters. The solution, coaches hold a variety of activities that are various, not monotonous, and not too busy to make employees bored by continuing to add time. For the problem of limited literature, it is hoped that the campus can reproduce books related to coaching materials.

\section{Conclusion}

Development of Al-Islam and Kemuhammadiyahan plays a significant role in instilling religious values for employees of the Muhammadiyah University of Ponorogo, namely by holding various kinds of religious development activities in the fields of aqidah, worship, and muamalah. The role in the field of aqidah of employees has a straight foundation of belief, namely in the form of faith values (pillars of faith), knowing and acknowledging that Allah SWT is the God who has the right to be worshiped and asked for help and pray only to Allah.

Meanwhile, in worship, employees have been able to perform ablution, obligatory prayers, and sunnah from movement to reading well, then fasting, zakat, qurban, and so on. These employees practice their religious practices according to the instructions of the Qur'an and are exemplified by the Prophet Muhammad SAW in the hadith. While the role in muamalah employees can interact with residents of the environment around the employee's residence well, respect the leadership, love colleagues, protect the environment, obey the applicable employment regulations and employees can carry out their duties and duties properly.

\section{References}

[1] A. Syukir, Dasar-Dasar Strategi Dakwah. Surabaya: Al-Ikhlas, 1983.

[2] A. Muslich, Pembinaan Al Islam dan Kemuhammadiyahan. Ponorogo: Umpo Press, 2016.

[3] F. Pringgayuda, Hubungan Penerapan Nilai-Nilai Kemuhammadiyahan dengan Upaya Menjaga Diri dari Infeksi di Rumah Sakit Muhammadiyah. Jakarta: Bumi Aksara, 2012.

[4] BPH, SK Tentang Pokok-Pokok Kepegawaian. Ponorogo: UMP Press, 2005.

[5] A. Ghuddah, 40 Strategi Pembelajaran Rasulullah. Yogyakarta: Tiara Wacana, 2005.

[6] A. Ghofir, Metodologi Pembelajaran Pendidikan Agama Islam. Malang: Universitas Negeri Malang, 2004.

[7] N. Sudjana, Penelitian dan Penilaian Pendidikan. Bandung: Sinar Baru, 1989.

[8] L. J. Moleong, Metodologi Penelitian Kualitatif. Bandung: Remaja Rosdakarya, 2010.

[9] S. Arikunto, Prosedur Penelitian. Jakarta: Rineka Cipta, 2002.

[10] S. Harini, Mendidik Anak Sejak Dini. Yogyakarta: Kreasi Wacana, 2003.

[11] S. Soekanto, Ensiklopedia Manajemen. Jakarta: Bumi Aksara, 2002. 